\title{
Branding Public Universities in Ghana: A Supply Chain Perspective
}

\author{
Mawuko Dza, Evans Kyeremeh and Samuel Affran
}

\begin{abstract}
Public universities in Ghana are funded by the state. In spite of this privilege, increased demand for improved facilities and the need for the introduction of innovative and competitive programmes, coupled with intense competition from their private counterparts have increased the pressure on these universities to either innovate or risk being crowded out from the market. The purpose of the paper is to investigate branding strategies adopted by public universities and their effects on meeting stakeholder expectations. The study analysed branding strategies of six public universities in Ghana. The findings revealed that most public universities' branding strategies focused mainly on improvement of physical infrastructure; the provision of state-of-the-art laboratories; broad band internet services; the introduction of market driven programmes; the mounting of huge signposts and pull-up banners among others. Indeed, the research revealed that the ultimate goal of branding these institutions is to be able to appeal to prospective students and attract wellqualified and competent faculty members. However, further findings point to the fact that little attention is paid to perhaps the most important stakeholders - the students, who according to the extant literature serve as major stakeholders and brand ambassadors for these institutions. This study is significant because it brings to the fore essentials of branding and brand strategies appropriate to academic institutions and also reorients educational authorities about the importance to rethinking the educational supply chain from the upstream through the midstream or the institutions through the downstream.
\end{abstract}

Keywords - Branding, Universities, Upstream, Educational Supply Chain.

\section{INTRODUCTION}

With the advent of competition in the tertiary education sub-sector, institutions of higher learning are devising strategies in order to remain relevant and competitive. For this reason, universities have deployed varied strategies to ensure that they meet stakeholder expectations. Invariably the major reason for ensuring that their institutions remain competitive is to attract prospective students from both within and outside the shores of the country. Others do this in order to attract and retain qualified and experienced faculty members. Thus branding and re-brand strategies have focused on improving physical infrastructure, acquiring innovative and state-of-the-art facilities and equipment, building and showcasing Information Technology infrastructure, acquiring modern teaching aids, among others. While all these brand strategies somewhat serve the purpose intended, especially in attracting prospective applicants and persuading experienced and qualified faculty members, these gains are short-lived, as it

Published on March 21, 2020.

Authors are with University of Education, Winneba, Ghana.

(corresponding email: dzama2010@gmail.com) is soon realized that the ultimate goal of these brand strategies are basically to increase students enrolment without considering students' expectations once they enroll. In Ghana, most parents prefer to enroll their wards in public universities. The reasons for their decision among others are, the relatively low fees charged; the presence of experienced and qualified faculty members; the comparatively high standards in teaching, learning and research; and the prestige society attaches to students who graduate from these institutions. These factors overshadow events that take place ones the students are admitted. It is at this point that most parents realize that their expectations may never be fulfilled. A visit to most public universities in Ghana shows how "inhumanely" some administrators and faculty members treat students. In fact, some administrators treat students as though they are not needed in the university. They use derogatory and abusive language on students with the slightest provocation and most often deliberately delay them unduly when they are seeking assistance in the form of document endorsements among others. On the other hand, some lecturers blatantly verbally abuse their students at lecture halls at the least instance with threats to even causing their failure in the course(s) they are enrolled on.

This paper seeks to unravel the effect of branding and branding strategies adopted by public universities on the educational supply chain. The research is significant because the act of branding is an expensive venture requiring lots of effort and investment. The question is, with the substantial capital outlay required to brand universities, does these institutions get the opportunity to reap the benefits of their investments especially where customer relation is relegated to the background? The originality of this article stems from the fact that, in Ghana branding public universities has traditionally been restricted to providing and improving mainly physical infrastructure and facilities at the expense of students. The paper therefore bridges the gap in literature by investigating the significance of customer relations in branding strategies of public universities in Ghana. The article thus contributes to the body of knowledge by unraveling the effect of human resource management on brand strategies in public universities in Ghana, a study area paucity of information.

\section{RE - BRANDING PUBLIC UNIVERSITIES IN GHANA}

In recent times, the subject of re-branding public universities has become a topical issue because of the competitive nature of the educational subsector. Most universities in Ghana adopt the proactive form of branding where institutions recognize an opportunity to grow, 
innovate, tap into new businesses, and to reconnect with its stakeholders [20]. As with other institutions, universities usually tweak their brand to keep themselves relevant and up-to-date. These changes can be an entire overhaul or minor tinkering as faculties attempt to attract new students and experienced staff. Universities and faculties are rebranding themselves at an increasing rate in order to keep pace with competition and new trends in the university education subsector [15]. Worth noting is the fact that rebranding universities is quite different from re-branding products or services [12]. Most universities rebrand themselves for various reasons including, the need to reach new frontiers; the desire to follow modern trends in university education by introducing innovation and technology to articulate brand value and brand experience for a new look [5]. It is important to note that, an identity without affinity is mere graphics; that is why it is significant that in all cases what consumers see should align with how they feel or how an institution wants them to feel rather than what the institution or senior management wants to express [20]. Apparently, most universities re-brand to correct an idea that is holding them back from the very people they are seeking to attract [20].

\section{BRANDING STRATEGIES OF UNIVERSITIES IN GHANA}

Available literature on re-branding strategies of educational supply chain is limited [16]. Impliedly, there are few specific branding strategies outlined in the extant literature. It is significant to acknowledge that, branding universities does not mean changing just the colour, logo, and embarking on technological deployment and infrastructural development. Indeed, all these might pass for branding but they are just tactics and not strategies. These minor changes certainly live under the auspices of branding universities and must be considered. But strategically, there is much more to branding than what has been discussed earlier. Universities need to wake-up to real branding strategies that attract more students. Branding universities means that universities must understand belief systems that control human behaviour and stop focusing on superficial issues [9]. Scholars such as [6]; [10], have advocated for increased 'managerialism' to reshape the image of institutions. University administrators have been cautioned to take institutional brand management more seriously to remain competitive in the market [16]. [8] Concludes that universities should undertake aggressive promotional activities as a branding strategy. Empirically, it is confirmed that a university with a strong brand attracts more students and increases retention rates [24]. Higher Education is also viewed as a service industry with a unique brand identity [9]. This purports that university branding must pay attention to the intangibility and inseparability aspects of their services. [4] Universities are service brand, which require greater emphasis on internal marketing, since all employees become consumer touch-points and service brands. Universities should develop a situation analysis process to establish position and enact effective strategies to present a positive image and reputation, in the mindset of the target market [19].

\section{THE ROLE OF BRAND AMBASSADORS' OF UNIVERSITIES IMAGE}

In the context of academic institutions, a brand ambassador's major goal is to develop and maintain a positive image of the institutions they graduated from [7]. Brand ambassadors play a major role in promoting specific brands, service or product that is produced in an institution [11]. These brand ambassadors who are basically volunteers are in continuous interaction with business partners, religious bodies, families and friends, among others, to promote and advertise the services, brand names, and programmes of their institutions. Brand ambassadors' provide institutions with important information in a wellorganized manner for prospective students and faculty [13]. For the work of brand ambassadors to yield results, they ought to have some level of influence, be loyal, and should be genuinely interested in championing the good image of their institutions and must be willing to live by the institution's values and conducts. The main objective of brand ambassadors for academic institutions is to propagate and promote the ideals of the institution and to develop a consumer preference of a brand name. Apart from this, brand ambassadors are required to provide complete data regarding the service or brand to the prospective students and faculty, thereby, increasing the visibility of their institution [18]. It is essential to acknowledge that an important role brand ambassador play for institutions is to represent them whenever they can and wherever they find themselves [8]. An ambassador thus becomes the mouthpiece of the institution, in words and in deeds; to completely project the image of the institution in every means possible [1].

\section{METHODS}

This study adopted the descriptive analysis approach. Data was collected from 235 respondents, made up of 45 administrators, 55 faculty members, 85 current students and 50 past students. The respondents were randomly sampled to solicit information on the issue of branding of various universities in Ghana. The analysis comprises of mean, percentage and analysis on correlation, hypothesis testing and multiple linear regression analysis.

\section{DATA COLLECTION AND ANALYSIS}

Structured questionnaires were used to collect data from respondents. Ethical considerations were strictly adhered to as respondents were duly briefed on the objectives of the research after which informed consent forms were presented to them to voluntarily sign. It was also made clear to respondents that they could withdraw from the study if they were no longer interested. In essence, respondents could walk out of the research at any time if they so desire.

\section{HYPOTHESIS FORMULATION AND TESTING}

H1: There is a significant positive relationship between improving ICT facilities and attracting new students;

$\mathrm{H} 2$ : There is a significant positive relationship between 
developing physical infrastructure and attracting new students;

H3: There is a positive significant relationship between modern institutional facilities and attracting experienced faculties;

H4: There is a positive significant relationship between introducing market driven programmes and increased students' enrolment;

H5: There is a positive significant relationship between students' experience with staff and an increase in students' enrolment;

Table I: Descriptive Statistics

\begin{tabular}{lrrrr}
\hline \hline & Mean & \multicolumn{1}{c}{ Std. Deviation } & \multicolumn{1}{l}{ Skewness } & \multicolumn{1}{c}{ Kurtosis } \\
\hline H1 & 6.3319 & 1.77122 & 1.907 & 5.080 \\
H2 & 4.9149 & 1.98961 & 2.391 & 5.080 \\
H3 & 4.7702 & 1.70669 & 2.652 & 6.834 \\
H4 & 4.7191 & 1.36103 & 2.377 & 5.787 \\
H5 & 3.9915 & 1.72461 & 1.707 & 2.051 \\
\hline \hline
\end{tabular}

The table shows the descriptive statistics, normalities and reliabilities of the various variables. All the variables displayed high reliabilities. All the five variables for the constructs passed the initial test of reliability as they were far above the recommended threshold of 0.70 . Hence, all the instruments for the study were acceptable. According to [23] an instrument is considered normal when its Skewness and Kurtosis ranges from -2 to +2 . Implying that, most of the instruments for the study were normal since they were found to be within the normality range. To indicate the dominant branding strategy used by most public universities in Ghana, mean scores of the five branding strategies were computed. From the above table, the highest mean score was improving ICT Infrastructure $(\mathrm{M}=6.33$, $\mathrm{SD}=1.77$ ) followed by developing physical infrastructure $(\mathrm{M}=4.91, \mathrm{SD}=1.99)$ and lowest mean score was students' experience with staff $(\mathrm{M}=3.99, \mathrm{SD}=1.72)$. Therefore, it can be concluded that the most focused branding strategy in public Universities in Ghana is improving ICT facilities with little attention paid to Students experience with staff.

\begin{tabular}{lccccc}
\multicolumn{5}{c}{ Table II: Correlation Analysis } \\
\hline & 1 & 2 & 3 & 4 & 5 \\
\hline 1. Improving ICT facilities & 1 & & & & \\
2.Developing physical & & & & & \\
infrastructure & .425 & 1 & & & \\
$\begin{array}{l}\text { 3. Modern institutional } \\
\text { facilities }\end{array}$ & .462 & .489 & 1 & & \\
$\begin{array}{l}\text { 4. Introducing market } \\
\text { driven programmes }\end{array}$ & .152 & .116 & .237 & 1 & \\
$\begin{array}{l}\text { 5. Students' experience } \\
\text { with staff }\end{array}$ & .298 & .349 & .406 & .227 & 1 \\
\hline
\end{tabular}

**. Correlation is significant at the 0.01 level (2-tailed).

*. Correlation is significant at the 0.05 level (2-tailed).
The table above shows a positive relationship between the correlation factors or variables that affects branding of public universities in Ghana. Below are the factors that affect branding of public universities in Ghana. As hypothesized in $\mathrm{H}_{1}$ that there will be a significant positive relationship between improving ICT facilities and University branding, the Pearson's product correlation analysis displayed in table 2 confirmed that there exist a significant positive relationship between improving ICT facilities and branding. This implies that students mostly enroll at public universities because of their ICT infrastructure. Such ICT infrastructure includes Internet facilities, good public address system, electronic boards, Elearning platforms etc. These facilities attract students' enrollment into public universities. In testing for $\mathrm{H}_{2}$, the finding of the study supports the assertion that there is significant positive relationship between developing physical infrastructure and branding $(\mathrm{r}=.425, \mathrm{p}<.01)$. Students take into consideration the physical infrastructure of the university before enrolling into any tertiary institution. The analysis shows that universities with good physical infrastructure are more likely to attract more students.

The study also reveals that there is significant positive relationship between Modern institutional facilities and branding $(\mathrm{r}=.462, \mathrm{p}<.01)$. This result supports $\mathrm{H}_{3}$. This analysis shows that universities with modern institutional facilities are more likely to attract new students than universities with poor or weak institutional facilities. This is because students take into consideration the facilities the university provides to them before enrolling into that tertiary institution. Furthermore, it was found that there exist a positive significant relationship between Introducing market driven programmes and branding $(\mathrm{r}=.152, \mathrm{p}<.01)$. Confirming $\mathrm{H}_{4}$. It also means that universities that introduce market driven programmes are likely to attract more students' enrollment.

Finally, the analysis was used to test hypothesis $\mathrm{H}_{5}$ : which indicates that Students' experience with staff have positive significant impact on branding, the analysis confirmed and established the hypothesis $(r=.298, \mathrm{p}<.01)$. These results presuppose that there is a positive correlation between all the five independent variables and University Branding. However, it is worth noting that, the correlation value between modern facilities and developing physical infrastructure was higher indicating that administrators, students and faculty members' perceive that public universities in Ghana will match up competition from the private counterparts and also meet stakeholders' expectations if they focus more on attracting new students. In other words, attracting new students gives a unique identity to universities more than other branding strategies.

\section{REGRESSION ANALYSIS}

Regression analysis basically helps one to understand how a typical value of the dependent variable if the independent variables changes. In this case, University branding was used as the dependent variable and the independent variables included ICT infrastructure, physical infrastructure, institutional facilities, market driven 
programmes and student experience with staff. The results of the multiple regression analysis are presented and interpreted in the table below. The table reveals that university branding and the variables affecting it are significantly correlated with the coefficient $\mathrm{R}=0.247$ with the coefficient of determination $\mathrm{R}^{2}=0.061$ at a significant level of $\mathrm{p}=0.012$. The results show that university branding can be explained by the changes in ICT infrastructure, physical infrastructure, institutional facilities, market driven programmes and students' experience with staff. In addition, it gives the summarized ANOVA (analysis of variance) table and $\mathrm{F}$ statistics, which reveals the value of $\mathrm{F}$ (2.986) is significant at the 0.012 levels, which is less than 0.05 . This indicates that all or at least one of independent variables (ICT infrastructure, physical infrastructure, institutional facilities, market driven programmes and students' experience with staff) is a significant predictor of the dependent variable (University branding).

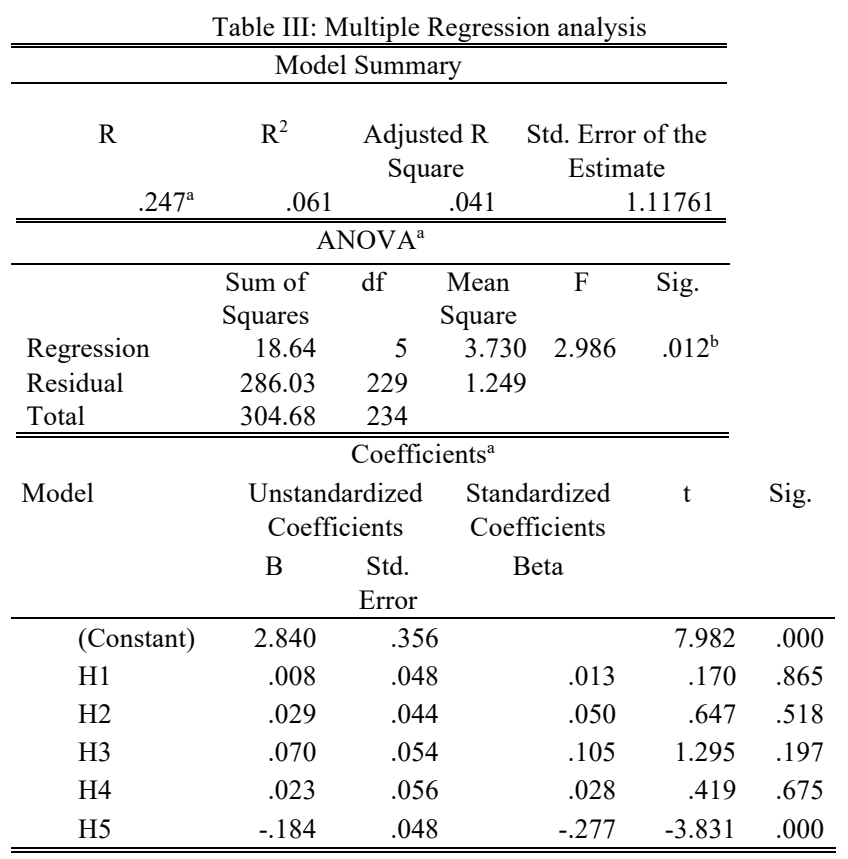

a. Predictors: ICT infrastructure, physical infrastructure, institutional facilities, market driven programs and student experience with staff.

\section{b. Dependent Variable: University branding}

Looking at the coefficients table, the coefficient for the constant is the value of $\mathrm{Y}$-intercept. The equation from this output is in the form of:

$Y=2.84+0.008 \times 1+0.029 \times 2+0.070 \times 3+0.023 \times 4-$ $0.184 x 5$

Where,

$Y$ represents University branding

$X 1$ Improving ICT facilities

$X 2$ Physical infrastructure

$X 3$ Institutional facilities

X4 Market driven programmes

X5 Student experience with staff
The relative importance of association of each independent variable was different. This was evaluated and interpreted by the coefficients of correlation (B). Improving ICT facilities positively affect university branding with $\beta=$ 0.008 at a significant level of 0.865 . This indicates that there is a positive relationship between the dependent value (University branding) and the independent value (Improving ICT facilities). So if ICT facilities improve by 1, University branding is predicted to go up by 0.865 though significant. Similarly, physical infrastructure positively affects University branding with $\beta=0.029$ at a significant level of .518. This indicates that the independent variable (physical infrastructure) have a positive relationship with the dependent variable (University branding). So if physical infrastructure goes up by 1 , university branding is predicted to go up by 0.518 . This shows that students are more likely to choose universities with good physical infrastructure than universities with poor physical infrastructure. Also, institutional facilities positively affect University branding with $\beta=0.070$ at a significant level .197. This indicates that the independent variable (institutional facilities) have a positive relationship with the dependent variable (University branding). So if institutional facilities increase by 1 , university branding is predicted to go up by 0.197 . Again, market driven programmes positively affect University branding with $\beta=$ 0.023 at a significant level of .675 . This indicates that the independent variable (market driven programmes) have a positive relationship with the dependent variable (University branding). So, if market driven programmes increase by 1 , university branding is predicted to go up by 0.023 .

\section{CONCLUSION}

The analysis shows that in branding public universities, more attention is given to infrastructural development, ICT facilities, introducing market driven programmes, and attracting knowledgeable and experienced faculty members than students' experience with faculty members and other staff. It is regrettable to state that in the $21^{\text {st }}$ century, educational authorities perhaps do not see students as their key stakeholders. For this reason students who are key stakeholders on the educational supply chain do not receive the needed courtesy they deserve. It is therefore not surprising that they are sometimes treated as though they mean nothing to the institutions. It is important to place on record that no matter the brand strategy that is deployed by public universities, the fact remains that if they continue to relegate students to the background, with time these institutions risk losing their credibility in the publics' eye as graduates from these institutions would embark on negative propaganda against their own universities. It is imperative to state that all stakeholders on the educational supply chain are important. That is why it behoves on educational institutions to treat students with dignity and respect just as other members of the chain are treated. 


\section{REFERENCES}

[1] Anholt, S. (2006). Public diplomacy and place branding: Where's the link.

[2] Anholt, S. (2006). The Anholt-GMI city brands index: How the world sees the world's cities. Place branding, 2(1), 18-31.

[3] Anholt, S. (2006). Why brand? Some practical considerations for nation branding.

[4] Berry, L. L. (2000). Cultivating service brand equity. Journal of the Academy of marketing Science, 28(1), 128-137.

[5] Botterill, J., \& Kline, S. (2007). From McLibel to McLettuce: Childhood, spin and re-branding. Society and Business review, 2(1), 74-97.

[6] Constanti, P., \& Gibbs, P. (2004). Higher education teachers and emotional labour. International Journal of Educational Management.

[7] De Oreck, K., Maon, F., \& Lejeune, C. (2013). Taking up the challenge of corporate branding: an integrative framework. European Management Review, 10(3), 137-151.

[8] Gilmore, F. (2002). A country - Can it be repositioned? Spain-The success story of country branding. Journal of Brand management, 9(4), 281-293.

[9] Hemsley-Brown, J., \& Goonawardana, S. (2007). Brand harmonization in the international higher education market. Journal of business Research, 60(9), 942-948.

[10] Hitchcock, C., Meyer, A., Rose, D., \& Jackson, R. (2002). Providing new access to the general curriculum: Universal design for learning. Teaching exceptional children, 35(2), 8-17.

[11] Kapferer, J. N. (2012). The new strategic brand management: Advanced insights and strategic thinking. Kogan page publishers.

[12] Kotler, P., \& Keller, K. L. (2012). Marketing Management (Vol. 14th ed.). New Jersey: Pearson Prentice Hall

[13] Lee, M. S., Motion, J., \& Conroy, D. (2009). Anti-consumption and brand avoidance. Journal of Business Research, 62(2), 169-180.

[14] McCollough, M. A., Berry, L. L., \& Yadav, M. S. (2000). An empirical investigation of customer satisfaction after service failure and recovery. Journal of service research, 3(2), 121137.

[15] Noaman, A. (2012). Higher education marketing trends for 20122013. Retrieved from: http://aha.elliance.com/2012/08/09/highereducation-marketing-trends-2012-2013/\#x2 010; education\&\#x2010;marketing\&\#x2010; trends\&\#x2010;2012\&\# x2010;2013/.

[16] Omar, M., Williams, R. L., \& Lingelbach, D. (2009). Global brand market-entry strategy to manage corporate reputation. Journal of Product \& Brand Management.

[17] Oplatka, I., \& Hemsley-Brown, J. (2007). The incorporation of market orientation in the school culture. International Journal of Educational Management.

[18] Roll, M. (2015). Asian brand strategy. In Asian Brand Strategy (Revised and Updated) (pp. 107-140). Palgrave Macmillan, London.

[19] Sirkeci, I. (2013). Transnational marketing and transnational consumers (p. 75). New York, Heidelberg, London: Springer.

[20) Somma, M. (2014), "Brand Strategy for lasting Value", http://www.brandingstrategyinsider.com/brand-loyalty, access date, February 18, 2014

[21] Tabachnick, B. G., \& Fidell, L. S. (2007). Using multivariate statistics. Boston: Pearson/Allyn \& Bacon.

[22] Tabachnick, B. G., Fidell, L. S., \& Ullman, J. B. (2007). Using multivariate statistics (Vol. 5). Boston, MA: Pearson.

[23] Tabachnick, B. G., \& Fidell, L. S. (2007). Experimental designs using ANOVA. Thomson/Brooks/Cole.

[24] Toma, I., Iqbal, K., Tausch, B., Heikkil, J., \& Roman, D. (2005). Evaluation of current effort in service and resource matchmaking. ASG Deliverable.

\section{BIOGRAPHY}

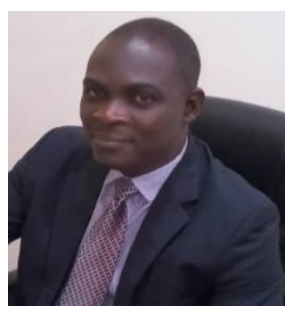

Mawuko Dza is a Ghanaian academic with specialization in Procurement and Supply Chain Management. The author holds a Ph.D. in Procurement and Supply Chain Management from Griffith University (Gold Coast Campus) Australia; an MSc. in Production and Logistics Management from Malardalen University (Eskilstuna and Vasteras Campuses) in Sweden; a BSc. in Banking and Finance from the University of Ghana, Legon- Accra.

He is currently a lecturer at the School of Business of the University of Education, Winneba, Ghana. He has a number of journal article publications to his credit including: Dza, M., Gapp, R. and Fisher, R. (2015) Taking the professionalism out of the profession: a study of Procurement and Africa, International Journal of Procurement Management 8(3) pp. 251 - 271; Dza, M., Fisher, R. \& Gapp, R. (2013) Procurement reforms in Africa: the Strides, Challenges and Improvement Opportunities, Public Administration Research 2(2) pp. 49 - 57

Dr. Dza is a member of Ghana Institute of Procurement and Supply (GIPS) and the Chartered Institute of Supply Chain Management, Ghana.

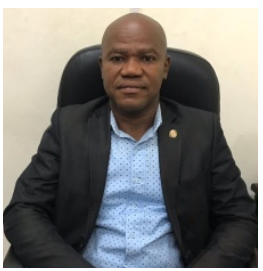

Evans Kyeremeh holds Master of Philosophy in Logistics and Supply Chain Management, Master of Business Administration in Logistics and Supply Chain Management and Bachelor of Science (Psychology). He is a Lecturer at the Department of Marketing, Procurement and Supply Chain Management, School of Business, University of Education, Winneba, Ghana. His area of research includes Supply Chain Management, Logistics, Warehousing and Material Handling and Corruption in Public Procurement. He has authored a number of articles in the subject area.

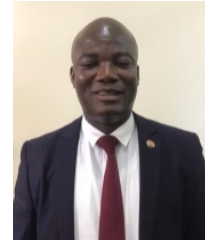

Mr. Samuel Affran holds an MPhil in Marketing management and currently pursing Ph.D. in Ghana Institute of Management and Public Administration, Accra Ghana. He is a lecturer at the Department of Marketing, Procurement and Supply Chain Management, School of Business, University of Education, Winneba, Ghana. Research interest are as follows; Marketing strategy, Customer relations and relationship 